Original research article

\title{
The efficiency of the patient fall prevention programme in selected medical institutions
}

\author{
Iva Brabcová ${ }^{1}{ }^{*}$, Hana Hajduchová ${ }^{1}$, Valérie Tóthová ${ }^{1}$, Sylva Bártlová ${ }^{1}$, Martin Doseděl ${ }^{2}$, \\ Josef Malý ${ }^{2}$, Aleš Kuběna ${ }^{2}$, Jiří Vlček ${ }^{2}$, Andrea Botíková ${ }^{3}$ \\ ${ }^{1}$ University of South Bohemia in České Budějovice, Faculty of Health and Social Sciences, Institute of Nursing, Midwifery and Emergency Care, \\ České Budějovice, Czech Republic \\ ${ }^{2}$ Charles University, Faculty of Pharmacy in Hradec Králové, Department of Social and Clinical Pharmacy, Hradec Králové, Czech Republic \\ ${ }^{3}$ Trnava University, Faculty of Health Care and Social Work, Department of Nursing Care, Trnava, Slovak Republic
}

\begin{abstract}
Introduction: Patient falls are frequent unwanted events. Hospital managements have the important task of implementing an efficient programme of patient fall prevention - which is complex, multifactorial and highly individualized.

The goal of this research was to assess the efficiency of the implemented fall prevention programme in selected South-Bohemian hospitals. Methods: This is an epidemiological, observational and interventional study. In 2018, 16 departments in 4 South-Bohemian hospitals implemented the intervention programme - the aim of which was to minimize risk factors of patient falls. All patients were included in the programme during the monitored period at selected workplaces. In 2017, 24,379 patients were included, and in 2018 there were 25,773 patients. We then monitored the efficiency of the implemented interventions. We assessed the differences between the incidence of falls in 2017 before the implementation of the intervention programme and the incidence of falls in 2018 during the realization of the programme. The fall index was set to the number of falls of 1,000 patients and the number of fall injuries during 1,000 days in hospital. Results: After the implementation of the prevention programme, the decrease in the number of falls was recorded at the departments of subsequent and rehabilitation care (from 39.12 to 30.9 falls/1,000 patients and from 0.79 to 0.58 falls with injuries/1,000 hospital days), departments of surgery (from 5.88 to 5.78 falls/1,000 patients and from 0.98 to 0.59 falls with injuries/1,000 hospital days) and the department of psychiatry (from 14.27 to 7.48 falls/1,000 patients and from 0.58 to 0.23 falls with injuries/1,000 hospital days). On the contrary, a higher fall index of falls was confirmed at internal departments (from 8.54 to 10.4 falls/1,000 patients and from 1.22 to 1.63 falls with injuries/1,000 hospital days).

Conclusions: The fall monitoring and the root analysis of their causes enable the managements of medical institutions to establish efficient remedial and preventative measures that decrease the incidence of falls and minimize their consequences.
\end{abstract}

Keywords: Falls; Index; Intervention; Patients; Prevention; Risk

\section{Introduction}

Fall prevention programmes in hospitals are designed to minimize risk factors of falls and correspond with primary hospitalization goals (which are treatment and patient activation). The establishment of the causes of falls and effective assessment of risk factors help to design efficient remedial and preventative measures. Regarding prevention, it is important to include a multidisciplinary approach, when a patient is treated by a team of nurses, doctors, physical therapists, nutritional therapists, ergotherapists or social workers. However, nurses are irreplaceable regarding the prevention of falls. They educate patients and family members about the issue of falls or implement general and individual interventions. Patient falls are multifactorial and their health conditions change during hospitalization, so they cannot be actively prevented in all cases. The efficiency of intervention programmes regarding the prevention of patient falls in hospitals has been dealt with in a number of studies (Ang et al., 2011; Banez et al., 2008; Dykes et al., 2010; Haines et al., 2004). The effectiveness of intervention programmes that are focused on the decrease of the risk of falls in elderly patients was dealt with by Cumming et al. (2008), Haines et al. (2011) or von Renteln-Kruse and Krause (2007). The conclusions of their studies point out the fact that intervention or technology alone cannot eliminate the risk of falls of patients in a hospital. The recent study of Shorr et al. (2012) evoked questions about an incommensurate reliance on bed alarms during fall prevention. Only complex and highly individualized interventions minimize the risk of falls in hospitals (Cameron et al., 2010).

\footnotetext{
* Author for correspondence: Iva Brabcová, University of South Bohemia in České Budějovice, Faculty of Health and Social Sciences, Institute of Nursing, Midwifery and Emergency Care, U Výstaviště 26, 37005 České Budějovice, Czech Republic; e-mail: brabcova@zsf.jcu.cz; http://doi.org/10.32725/kont.2019.055
}

Submitted: 2019-08-27 • Accepted: 2019-11-06 • Prepublished online: 2019-12-13

KONTAKT 22/2: 79-84 • EISSN 1804-7122 • ISSN 1212-4117

(c) 2019 The Authors. Published by University of South Bohemia in České Budějovice, Faculty of Health and Social Sciences.

This is an open access article under the CC BY-NC-ND license. 
The results of this prospective and exploratory qualitative study confirmed that medical workers should involve patients and their family members in preventative measures more, and introduce them to the risk factors that contribute to falls during hospitalization (Shuman et al., 2016). An important condition in successful fall prevention in acute hospital care is the regular education of nurses and changes in nursing practice (Koh et al., 2009). It is important to approach the system of fall prevention with innovations. Tzenga Yin (2014) developed a software application that enables the proactive involvement of patients in fall prevention during hospitalization.

Creating hospital committees for fall prevention can be a guarantee that implemented changes are kept to (Godlock et al., 2016). The involvement of managers in patient safety and the education of medical workers on this issue led to a decrease of the fall index at internal departments from 1.90 to 0.69/1,000 hospital days (Godlock et al., 2016). It is important to have management support, the engagement of the higher management, use of information technologies for data, and the education of medical workers (Weil, 2015).

\section{Goals}

- To establish the fall index of hospitalized patients in selected South Bohemian hospitals.

- To assess the effectiveness of the programme regarding fall prevention in clinical practice.

\section{Materials and methods}

The presented results are partial outcomes of the project 'Analysis of Factors Influencing Fall Risk - Options of the Involvement of Nurses and Pharmacists in Minimizing Such Risks'. The project is carried out by the Faculty of Health and Social Sciences of the University of South Bohemia in České Budějovice and the Faculty of Pharmacy of Charles University in Hradec Králové between 2016 and 2019. The focus of the research is the monitoring of falls and the analysis of fall risk factors - with a focus on falls caused by drugs.

It is an epidemiologic, observational and interventional study. The project involved four South Bohemian hospitals. In 2017 and 2018, all patient falls were monitored at 16 departments in the hospitals. The following departments recorded the highest number of falls: internal, departments of surgery, departments of subsequent and rehabilitation care, and psychiatry (Hajduchová et al., 2016). At every department, the administered doctors and nurses uploaded the fall data using an interactive database - which enabled pharmacists to carry out the immediate post-fall drug audit. If there are pharmaceutical causes of falls, pharmacists could suggest changes in medication.

At the same time in 2018, a preventative intervention programme was carried out in these departments. Its goal was to minimize the risk of falls of hospitalized patients. The intervention programme was implemented for all hospitalized patients at selected departments in the monitored period. In 2017, there were 24,379 patients and in 2018, there were 25,773 patients. Before the start of the programme, medical workers (nurses, doctors, clinical pharmacists and physiotherapists) were educated in fall prevention. The suggested group of interventions included general interventions that were carried out in all patients and individual interventions that were focused on patients at risk of falling. General interventions included the assessment of the risk of fall of all patients during admission, the re-assessment of the risk of falls at regular intervals, ensuring a safe environment during hospitalization, and the education of patients on general fall prevention. Individual preventative interventions were carried out in patients at risk of falling, such as educating patients about individual risks of fall (education on the negative effects of drugs, using compensational aids, safety during motion or transfers etc.), marking the beds of fall risk patients with a warning sign, and ensuring there was an alarm bell at patients' beds. Nurses co-operated with physiotherapists and provided patients with suitable compensational and safety aids. In cases when a fall did occur, there was an after-fall drug audit. The intervention programme included a multidisciplinary team of medical workers (nurses, doctors, pharmacists, physiotherapists, as well as nutritional specialists and ergotherapists). Subsequently, the efficiency of the programme was assessed by comparing the fall indexes in the year before the implementation of the programme (2017) with the fall indexes in 2018. The fall index was established to the number of falls/1,000 patients and the number of injuries caused by falls/1,000 hospital days.

The results were processed using descriptive statistical methods and were statistically assessed using the Wilcoxon test. The level of significance was set to $5 \%(p=0.05)$.

\section{Results}

After carrying out the preventative programme in 2018, the number of falls at the departments of subsequent and rehabilitation care decreased from 152 cases in 2017 (3.1\%) to 112 cases in 2018 (3.09\%). The number of injuries as a result of falls also decreased from 152 (67.11\%) to 65 (58.04\%). The fall index also decreased. The number of falls/1,000 patients decreased from 39.12 (2017) to 30.9 in 2018. The number of injuries caused by falls/1,000 hospital days decreased from 0.79 in 2017 to 0.58 in 2018 (Table 1).

In 2018, at internal departments (and one pulmonary department) there was a higher number of falls in comparison to 2017 - which was reflected in absolute numbers (from 122 to $159)$ and relative numbers. In $2017,0.85 \%$ of patients fell. In 2018, it was $1.04 \%$. However, in terms of relative percentage,

\begin{tabular}{lccc}
\hline $\begin{array}{l}\text { Table 1. Index of falls - Department of subsequent and } \\
\text { rehabilitation care (2017 and 2018) }\end{array}$ & & \\
\hline $\begin{array}{l}\text { Department of subsequent and } \\
\text { rehabilitation care (6 departments) }\end{array}$ & 2017 & 2018 & $\begin{array}{c}\text { Trends } \\
\uparrow \downarrow\end{array}$ \\
\hline Total number of patients & 3,885 & 3,625 & $\downarrow$ \\
Number of hospital days & 128,597 & 111,781 & $\downarrow$ \\
Average hospitalization length (days) & 33.10 & 30.84 & $\downarrow$ \\
Number of beds & 412 & 412 & - \\
Use of beds (lining) \% & 85.51 & 74.33 & $\downarrow$ \\
Number of falls & 152 & 112 & $\downarrow$ \\
Percentage of falls \% & 3.91 & 3.09 & $\downarrow$ \\
Number of injuries & 102 & 65 & $\downarrow$ \\
Percentage of injuries \% & 67.11 & 58.04 & $\downarrow$ \\
Serious injuries & 27 & 23 & $\downarrow$ \\
Percentage of serious injuries \% & 26.47 & 35.39 & $\uparrow$ \\
Number of falls/1,000 patients & $\mathbf{3 9 . 1 2}$ & $\mathbf{3 0 . 9 0}$ & $\downarrow$ \\
Number of injuries/1,000 & $\mathbf{0 . 7 9}$ & $\mathbf{0 . 5 8}$ & $\downarrow$ \\
hospital days & & & \\
\hline
\end{tabular}


there was a decrease in injuries caused by falls (from $93.44 \%$ to $79.87 \%$ ). If patients were injured due to a fall, there was an increase in serious injuries in the monitored period (from $8.77 \%$ to $11.02 \%)$. The index of falls also increased in the number of falls/1,000 patients (from 8.54 to 10.4) as well as the number of injuries/1,000 hospital days (from 1.22 to 1.63) - Table 2.

\begin{tabular}{lccc}
$\begin{array}{l}\text { Table 2. Index of falls - Internal and pulmonary } \\
\text { departments (2017 and 2018) }\end{array}$ & & & \\
\hline $\begin{array}{l}\text { Internal and pulmonary } \\
\text { departments (6 internal } \\
\text { departments and 1 pulmonary } \\
\text { department) }\end{array}$ & 2017 & 2018 & $\begin{array}{c}\text { Trends } \\
\uparrow \downarrow\end{array}$ \\
\hline Total number of patients & & & \\
Number of hospital days & 14,279 & 15,295 & $\uparrow$ \\
Average hospitalization length (days) & 63,816 & 77,800 & $\downarrow$ \\
Number of beds & 326 & 5.09 & $\downarrow$ \\
Use of beds (lining) \% & 78.84 & 65.38 & $\downarrow$ \\
Number of falls & 122 & 159 & $\uparrow$ \\
Percentage of falls \% & 0.85 & 1.04 & $\uparrow$ \\
Number of injuries & 114 & 127 & $\uparrow$ \\
Percentage of injuries \% & 93.44 & 79.87 & $\downarrow$ \\
Serious injuries & 10 & 14 & $\uparrow$ \\
Percentage of serious injuries \% & 8.77 & 11.02 & $\uparrow$ \\
Number of falls/1,000 patients & $\mathbf{8 . 5 4}$ & $\mathbf{1 0 . 4 0}$ & $\uparrow$ \\
Number of injuries/1,000 & $\mathbf{1 . 2 2}$ & $\mathbf{1 . 6 3}$ & $\uparrow$ \\
hospital days & & & \\
\hline
\end{tabular}

Two surgical departments recorded the increase of the absolute number of patients and cases of falls. The relative percentage of falls in the total number of patients remained at $0.58 \%$. The index of falls decreased from 5.88 falls $/ 1,000$ patients in 2017 to 5.78 falls/1,000 patients in 2018. The number of injuries/1,000 hospital days decreased from 0.98 in 2017 to 0.59 in 2018. Despite the fact that the percentage of patients who were injured due to a fall decreased from $68.75 \%$ to $45.71 \%$ in the monitored period, the percentage of serious injuries due to a fall increased from $13.64 \%$ in 2017 to $25 \%$ in 2018 (Table 3).

The number of patients at psychiatric departments increased in 2018 (compared to 2017 - from 771 to 802). At the same time, the number of falls decreased (2017 - 11 falls, $1.43 \%$; 2018 - 6 falls, $0.75 \%$ ) and the index of falls also decreased. The number of injuries due to a fall also decreased from $72.73 \%$ in 2017 to $50 \%$ in 2018 . However, during the monitored period there was an increase in the relative percentage of serious injuries due to a fall (from $62.5 \%$ to $66.67 \%$ ) Table 4.

\section{Statistical assessment of the index of fall by departments}

Of the 16 monitored departments, 10 recorded a decrease in the index of falls and 6 recorded an increase. The change in the non-parametric test is not significant ( $p=0.737$, the Wilcoxon test). The change in the total number of falls is also insignificant ( $p=0.716$, GLMM Poisson log model with an offset). The model takes different sizes of departments into consideration. We cannot say that the implemented intervention programme statistically significantly decreased the risk of falls at selected

\begin{tabular}{lccc}
$\begin{array}{l}\text { Table 3. Index of falls - Surgical departments } \\
\text { 2018) }\end{array}$ & 2017 and \\
$\begin{array}{l}\text { Surgical departments } \\
\text { (2 departments) }\end{array}$ & 2018 & $\begin{array}{c}\text { Trends } \\
\uparrow \downarrow\end{array}$ \\
\hline Total number of patients & 5,444 & 6,051 & $\uparrow$ \\
Number of hospital days & 22,602 & 27,270 & $\uparrow$ \\
Average hospitalization length (days) & 4.15 & 4.51 & $\uparrow$ \\
Number of beds & 127 & 127 & - \\
Use of beds (lining) \% & 48.76 & 62.90 & $\uparrow$ \\
Number of falls & 32 & 35 & $\uparrow$ \\
Percentage of falls \% & 0.58 & 0.58 & - \\
Number of injuries & 22 & 16 & $\downarrow$ \\
Percentage of injuries \% & 68.75 & 45.71 & $\downarrow$ \\
Serious injuries & 3 & 4 & $\uparrow$ \\
Percentage of serious injuries \% & 13.64 & 25 & $\uparrow$ \\
Number of falls/1,000 patients & $\mathbf{5 . 8 8}$ & $\mathbf{5 . 7 8}$ & $\downarrow$ \\
Number of injuries/1,000 & $\mathbf{0 . 9 8}$ & $\mathbf{0 . 5 9}$ & $\downarrow$ \\
hospital days & & & \\
\hline
\end{tabular}

\begin{tabular}{lccc}
$\begin{array}{l}\text { Table 4. Index of falls - Psychiatric department (2017 and } \\
\text { 2018) }\end{array}$ & 2017 & 2018 & $\begin{array}{c}\text { Trends } \\
\uparrow \downarrow\end{array}$ \\
$\begin{array}{l}\text { Psychiatric department } \\
\text { (1 department) }\end{array}$ & 771 & 802 & $\uparrow$ \\
\hline Total number of patients & 13,767 & 12,928 & $\downarrow$ \\
Number of hospital days & 17.86 & 16.12 & $\downarrow$ \\
Average hospitalization length (days) & 42 & 42 & - \\
Number of beds & 89.90 & 84.30 & $\downarrow$ \\
Use of beds (lining) \% & 11 & 6 & $\downarrow$ \\
Number of falls & 1.43 & 0.75 & $\downarrow$ \\
Percentage of falls \% & 8 & 3 & $\downarrow$ \\
Number of injuries & 72.73 & 50 & $\downarrow$ \\
Percentage of injuries \% & 5 & 2 & $\downarrow$ \\
Serious injuries & 62.5 & 66.67 & $\uparrow$ \\
Percentage of serious injuries \% & $\mathbf{1 4 . 2 7}$ & $\mathbf{7 . 4 8}$ & $\downarrow$ \\
Number of falls/1,000 patients & $\mathbf{0 . 5 8}$ & $\mathbf{0 . 2 3}$ & $\downarrow$ \\
Number of injuries/1,000 & & & \\
hospital days & &
\end{tabular}

departments. However, we can say that these departments did not record an increase in the risk of falls. Statistical insignificance does not show the non-existing efficiency. Nevertheless, the effect size estimate is $\eta^{2}=0.022$ ( $2.2 \%$ variability, small effect size by Cohen's convention). We can say that the change between the monitored years 2017 and 2018 is small.

After comparing the fall index in our research to the referential values of the Czech Association of Nurses (CAN), we can say that the index of falls in 2018 - after the implementation of the intervention programme at the departments of subsequent and rehabilitation care - is lower (0.58 injuries/1,000 hospital days) than the referential value of the CAN (0.79 injuries/1,000 hospital days). However, higher values of the index of falls were recorded at psychiatric, internal and surgical departments.

After comparing the index of falls with the referential values of the Institute of Health Information and Statistics of the 
Czech Republic (IHIS), we recorded lower values at the departments of internal and subsequent care. Higher numbers of falls/1,000 patients than the referential values of IHIS were established in surgical and psychiatric departments (Table 5).

Table 5. Comparison of the index of falls in this research to the referential values of CAN (2015) and IHIS (2016)

\begin{tabular}{|c|c|c|c|c|c|c|}
\hline \multirow[t]{2}{*}{ Results } & \multicolumn{2}{|c|}{ Number of injuries/1,000 hospital days } & \multirow{2}{*}{$\begin{array}{c}\text { Difference } \\
\uparrow \downarrow\end{array}$} & \multicolumn{2}{|c|}{ Number of falls $/ 1,000$ patients } & \multirow{2}{*}{$\begin{array}{c}\text { Difference } \\
\uparrow \downarrow\end{array}$} \\
\hline & CAN & Our research 2018 & & IHIS & Our research 2018 & \\
\hline Summary & 0.49 & 0.92 & $\uparrow$ & 28.4 & 12.11 & $\downarrow$ \\
\hline Subsequent care departments & 0.79 & 0.58 & $\downarrow$ & 90.2 & 30.90 & $\downarrow$ \\
\hline Internal departments & 0.67 & 1.63 & $\uparrow$ & 14.1 & 10.40 & $\downarrow$ \\
\hline Surgical departments & 0.25 & 0.59 & $\uparrow$ & 3.5 & 5.78 & $\uparrow$ \\
\hline Psychiatric departments & - & 0.23 & - & 5.8 & 7.48 & $\uparrow$ \\
\hline
\end{tabular}

Note: CAN - the Czech Association of Nurses, referential values of the index of falls for 2015 (percentage of injuries/1,000 hospital days).

IHIS - the Institute of Health Information and Statistics, referential values of the index of falls for the 2nd half of 2016 (number of falls/1,000 patients) for the 2nd half of 2016.

\section{Discussion}

Patient falls after suffering decubitus ulcers are the most frequently reported adverse events in Czech hospitals (IHIS, 2016). Due to the fact that the causes of patient falls are multifactorial, designing an effective preventative programme is difficult (Ang et al., 2011). The goal of this study was to assess the efficiency of the intervention programme regarding fall prevention in selected South Bohemian hospitals. In 2018, the intervention programme was carried out at 16 departments in four South Bohemian hospitals. The project included departments with the highest incidence of falls, i.e. the departments of subsequent and rehabilitation care, internal, surgical, and one psychiatric department. The project also involved multidisciplinary teams of nurses, doctors and clinical pharmacists whose goal was to minimize the risk of falls of hospitalized patients. It is not only nurses who work on plans of care - other employees do as well. Physiotherapists and clinical pharmacists are important contributors to the prevention of falls and must be part of the care planning process (Ganz et al., 2013).

In our study, the highest relative incidence of falls was recorded at the departments of subsequent and rehabilitation care. In 2017, before the establishment of the intervention programme, these departments recorded that $3.91 \%$ of patients had fallen. After establishing the programme it was $3.09 \%$. It is positive that the percentage of injuries in the monitored period decreased (from $67 \%$ before the programme to $58 \%$ after establishing the programme) - Table 1 . After the establishment of the programme, the fall index decreased at the departments of subsequent and rehabilitation care - from 39.12 to 30.09 falls/1.000 patients and from 0.79 to 0.58 injuries/1.000 hospital days (Table 1). When we compare the values in the research by CAN (2015) and IHIS (2016), our values are significantly lower (Table 5). In 2016, 98 healthcare providers reported adverse events to the System for Reporting Adverse Events (IHIS, 2016). The project of CAN, which was focused on the assessment of the reports of hospitalized patient falls, involved 38 medical institutions in 2015. 4,325 cases were assessed (CAN, 2015).

According to JCI (2007), institutions for the long-term ill recorded from 11 to 24.9 falls/1,000 hospital days, rehabilitation centres from 8 to 19.8 , and the percentage of injuries was between 29 and $48 \%$ (of which $4-7.5 \%$ were serious injuries).
The study of Lara-Medrano et al. (2014) proved the efficiency of the intervention programme for fall prevention at internal departments. The number of falls/1,000 hospital days decreased from 1.9 in 2007 to 0.67 between 2008 and 2013 (Lara Medrano et al., 2014). Due to this fact, it is surprising that our study regarding internal departments shows an increase in the percentage of falls (from $0.85 \%$ before establishing the programme to $1.44 \%$ after establishing the programme). The fall index regarding falls/1,000 patients also increased (from 8.54 to 10.4) as well as the number of falls caused injuries/1,000 hospital days (from 1.22 to 1.63 ) - Table 2. These values are higher than the referential values of the national research by CAN (2015) and lower than the values of IHIS (2016) - Table 5. Despite established changes, internal departments did not record a decrease in falls. There may be various reasons for this failure. The medical personnel could have been insufficiently educated in prevention, the education could have been focused mainly on general interventions and less on individual interventions, or the medical personnel were more willing to report falls in the hospital system of reporting adverse events.

In the study of Luzia et al. (2018), in which the monitoring period was between 2011 and 2015, the incidence of falls was higher at internal departments than surgical departments. These results correspond with ours. At surgical departments, the fall index decreased from 5.88 before establishing the intervention programme to 5.78 falls/1,000 patients after establishing the intervention programme, and from 0.98 injuries/1,000 hospital days before establishing the intervention programme to 0.59 after establishing the intervention programme (Table 3 ). These index values are higher than the referential values of IHIS (2016) and CAN (2015) - Table 5.

Psychiatric departments recorded the largest decrease in the percentage of falls (from $1.43 \%$ to $0.75 \%$ ). During the intervention programme, the fall index also decreased from 14.27 to 7.48 falls/1,000 patients (Table 4). Despite this fact, it is higher than the referential values of IHIS (2016) (Table 5).

The efficiency of the intervention prevention programme of hospitalized patient falls was studied in numerous researches. The study of Heines et al. (2004) proved a statistically significant decrease in fall incidence of patients included in the programme (11.2 falls/1,000 hospital days) compared to the control group of patients (16.1 falls/1,000 hospital days). The study of Dykes et al. (2010) verified the efficiency of the established intervention programme (intervention group 3.15 falls/1,000 hospital days, control group -4.18 falls/1,000 
hospital days). The study of Ang et al. (2011) recorded $0.4 \%$ of falls of patients included in the programme, whereas the control group showed $1.5 \%$. Our research also proved a positive influence on patient falls when the intervention programme was established. However, the decrease in the fall index was not statistically significant. It is a trend that is necessary to verify. We are aware of the limits of this study, which lie in the short time period of fall monitoring. We did not study the long-term maintenance of established interventions. At the same time, there is not one operationalization of the term fall, monitoring methods and the assessment of patient falls in the Czech Republic. Some hospitals only report falls with injuries and others do not consider a slide off a chair to be a fall. The methods of the assessment of fall index are also different. It is suitable for hospitals to choose a method for the assessment of the fall index and follow the trends at other departments. According to Botíková et al. (2015), not all medical institutions in Slovakia have a central system for reporting falls. A patient's fall is recorded in their medical documentation at best. It would be suitable to document every fall in a protocol with a date and time of fall, place, description, cause, information about injuries and remedial measurements. Such a central system enables the effective assessment of the causes of falls, the identification of risk factors and the effective establishment of preventative measurements to decrease the risk of fall. The question is whether nurses are willing to report patients' falls in hospital central systems for reporting adverse events. It is necessary that hospitals establish a non-pressurizing system for reporting adverse events that would motivate (not dis- courage) medical workers to report mistakes. It is important that every fall is recorded (including sliding off a chair) for the maintenance of care continuity. If a nurse does not report a fall during a shift change and the patient's condition worsens, the medical team may take too much time to find the cause of the patient's worsened condition - which leads to the risk of prolonging the provision of necessary care.

\section{Conclusions}

The results of this study have shown that the established intervention programme positively affected the number of falls of patients at surgical and psychiatric departments and departments of subsequent and rehabilitation care. However, the decrease was not statistically significant. The programme did not have any influence regarding internal departments. We are aware that establishing changes in practice is not sufficient. A much more difficult step is ensuring that these changes are part of long-term clinical practice.

\section{Research financing}

Supported by the programme project of the Ministry of Health, reg. No. 16-33463A. All rights by the regulation regarding the protection of intellectual property are reserved.

\section{Conflict of interests}

The authors have no conflict of interests to declare.

\title{
Účinnost programu prevence pádů pacientů ve vybraných zdravotnických zařízeních
}

\begin{abstract}
Souhrn
Úvod: Pády pacientů patři mezi časté nežádoucí události. Je důležitou úlohou managementu nemocnic zavést do praxe efektivní program prevence pádů pacientů, který je komplexní, multifaktoriální a zároveň vysoce individualizovaný.

Cílem výzkumu bylo vyhodnotit účinnost zavedeného intervenčního programu prevence pádů hospitalizovaných pacientů ve vybraných nemocnicích Jihočeského kraje.

Metodika: Jednalo se o epidemiologickou studii observačního a intervenčního typu. V roce 2018 byl na 16 odděleních čtyř nemocnic Jihočeského kraje zaveden intervenční program, jehož cílem bylo minimalizovat rizikové faktory pádů pacientů. Intervenční program byl zaveden u všech pacientů hospitalizovaných ve sledovaném období na vybraných pracovištích. V roce 2017 šlo o 24379 pacientů a v roce 2018 o 25773 pacientů. Následně byla sledována účinnost zavedených intervencí. Byl vyhodnocen rozdíl ve výskytu pádů v období 2017 před intervenčním programem a v roce 2018 v době realizace programu. Index pádů byl stanoven jako počet pádů na 1000 pacientů a počet zranění z pádu na 1000 lůžkodnů.

Výsledky: Po zavedení preventivního intervenčního programu byl pokles pádů zaznamenán na odděleních následné a rehabilitační péče (z 39,12 na 30,9 pádů/1 000 pacientů a z 0,79 na 0,58 pádů se zraněním/1 000 lůžkodnů), na chirurgických odděleních (z 5,88 na 5,78 pádů/1 000 pacientů a z 0,98 na 0,59 pádů se zraněním/1 000 lůžkodnů) a oddělení psychiatrie (z 14,27 na 7,48 pádů/1 000 pacientů a z 0,58 na 0,23 pádů se zraněním/1 000 lůžkodnů). Naopak vyšší index pádů byl potvrzen na interních odděleních (z 8,54 na 10,4 pádů/1 000 pacientů a z 1,22 na 1,63 pádů se zraněním/1 000 lůžkodnů).

Závěr: Monitoring pádů a kořenová analýza jejich př́ičin umožňuje managementu zdravotnických zařízení nastavit účinná nápravná a preventivní opatření snižující výskyt pádů a minimalizující jejich důsledky.
\end{abstract}

Klíčová slova: index; intervence; pacienti; pády; prevence; riziko

\section{References}

1. Ang E, Mordiffi SZ, Wong HB (2011). Evaluating the use of a targeted multiple intervention strategy in reducing patient falls in an acute care hospital: a randomized controlled trial. J Adv Nurs 67(9): 1984-1992. DOI: 10.1111/j.13652648.2011.05646.x.

2. Banez C, Tully S, Amaral L, Kwan D, Kung A, Mak K, et al. (2008). Development, Implementation, and Evaluation of an Interprofessional Falls Prevention Program for Older Adults.
J Am Geriatr Soc 56(8): 1549-1555. DOI: 10.1111/j.15325415.2008.01790.x.

3. Botíková A, Dziacka A, Martinková J, Ofčarovičová V (2015). Riziká pádov u geriatrických pacientov. In: Nové trendy v ošetrovatel'stve II. Trnava: Trnavská univerzita v Trnave, Fakulta zdravotníctva a sociálnej práce. CD.ROM, pp. 68-75.

4. Cameron ID, Murray GR, Gillespie LD, Robertson MC, Hill KD, Cumming RG, Kerse N (2010). Interventions for preventing falls in older people in nursing care facilities and hospitals. Cochrane Database Syst Rev (1): CD005465. DOI: 10.1002/14651858. cd005465.pub2. 
5. Cumming RG, Sherrington C, Lord SR, Simpson JM, Vogler C, Cameron ID, Naganathan V (2008). Cluster randomised trial of a targeted multifactorial intervention to prevent falls among older people in hospital. BMJ 336(7647): 758-760. DOI: 10.1136/bmj.39499.546030.be.

6. ČAS - Česká asociace sester (2015). Sledování pádů u hospitalizovaných pacientů v roce 2015 (závěrečná zpráva). [online] [cit. 2018-03-10]. Available from: https://www.cnna.cz/ docs/tiskoviny/zaverecna_zprava_pady_2015.pdf

7. Dykes PC, Carroll DL, Hurley A, Lipsitz S, Benoit A, Chang F, et al. (2010). Fall prevention in acute care hospitals. JAMA 304(17): 1912-1918. DOI: 10.1001/jama.2010.1567.

8. Ganz DA, Huang C, Saliba D, Shier V, Berlowitz D, Lukas C, et al. (2013). Preventing falls in hospitals: a toolkit for improving quality of care. Rockville, MD: Agency for Healthcare Research and Quality. AHRQ Publication No. 13-0015-EF. [online] [cit. 2018-03-10]. Available from: https://www.ahrq.gov/sites/ default/files/publications/files/fallpxtoolkit.pdf

9. Godlock G, Christiansen M, Feider L (2016). Implementation of an Evidence-Based Patient Safety Team to Prevent Falls in Inpatient Medical Units. Medsurg Nurs 25(1): 17-23.

10. Haines TP, Bennell KL, Osborne RH, Hill KD (2004). Effectiveness of targeted falls prevention programme in subacute hospital setting: randomised controlled trial. BMJ 328(7441): 676. DOI: 10.1136/bmj.328.7441.676.

11. Haines TP, Hill A-M, Hill KD, McPhail S, Oliver D, Brauer S, Beer C (2011). Patient education to prevent falls among older hospital inpatients. Arch Intern Med 171(6): 516-524. DOI: 10.1001/archinternmed.2010.444.

12. Hajduchova H, Brabcova I, Tothova V, Bartlova S (2016). Retrospective analysis of falls in selected hospitals of the Czech Republic. Neuro Endocrinol Lett 37(Suppl. 2): 18-24.

13. JCI - Joint Commission International (2007). Prevence pádů ve zdravotnickém zařízení (Cesta k dokonalosti a zvyšování kvality). Praha: Grada, p. 171.

14. Koh SL, Hafizah N, Lee JY, Loo YL, Muthu R (2009). Impact of a fall prevention programme in acute hospital settings in Singapore. Singapore Med J 50(4): 425-432.
15. Lara-Medrano R, Alcázar-Quiñones C, Galarza-Delgado DÁ, Baena-Trejo L (2014). Impact of a fall prevention program in the Internal Medicine wards of a tertiary care university hospital. Medicina Universitaria. 16(65): 156-160.

16. Luzia MF, Cassola TP, Suzuki LM, Dias VLM, Pinho LB, Lucena AF (2018). Incidence of falls and preventive actions in a University Hospital. Rev Esc Enferm USP 52: e03308. DOI: 10.1590/S1980-220X2017024203308.

17. Shorr RI, Chandler AM, Mion LC, Waters TM, Liu M, Daniels MJ, et al. (2012). Effects of an intervention to increase bed alarm use to prevent falls in hospitalized patients. Ann Intern Med 157(10): 692-699. DOI: 10.7326/0003-4819-15710-201211200-00005.

18. Shuman C, Liu J, Montie M, Galinato JG, Todd MA, Hegstad M, Titler M (2016). Patient perceptions and experiences with falls during hospitalization and after discharge. Appl Nurs Res 31: 79-85. DOI: 10.1016/j.apnr.2016.01.009.

19. Tzeng HM, Yin C-Y (2014). I Engaging as an innovative approach to engage patients in their own fall prevention care. Patient Prefer Adherence 8: 693-700. DOI: 10.2147/PPA. S62746.

20. ÚZIS (2016). Systém hlášení nežádoucích událostí. Nežádoucí události za 2. pololetí roku 2016 Analýza pilotního sběru agregovaných údajů. [online] [cit. 2018-01-05]. Available from: http://shnu.uzis.cz/res/file/SHNU_data_2016_2_souhrnna_ analyza_web_doplneno_FINAL_na_web.pdf

21. Von Renteln-Kruse W, Krause T (2007). Incidence of in-hospital falls in geriatric patients before and after the introduction of an interdisciplinary team-based fall-prevention intervention. J Am Geriatr Soc 55(12): 2068-2074. DOI: 10.1111/j.15325415.2007.01424.x.

22. Weil TP (2015). Patient falls in hospitals: An increasing problem. Geriatr Nurs 36(5): 342-347. DOI: 10.1016/j. gerinurse.2015.07.004. 